\title{
Efforts to improve by provision of infrastructure services and extracuricular implementation learning achievement
}

\author{
Aminah Aminah ${ }^{1}$, Edi Harapan ${ }^{2}$, Achmad Wahidy ${ }^{2}$ \\ ${ }^{1}$ Madrasah Tsanawiyah Negeri Sekecamatan Sekayu, Indonesia \\ ${ }^{2}$ Universitas PGRI Palembang, Indonesia
}

\begin{tabular}{l} 
Article Info \\
\hline Article history: \\
Received Jun $12^{\text {th }}, 2021$ \\
Revised Aug $19^{\mathrm{h}}, 2021$ \\
Accepted Aug 30,2021 \\
\hline
\end{tabular}

\section{Keyword:}

Learning achievement

Technology

Extracurricular

\begin{abstract}
The main objective of this research is to define and explain, through the provision of facilities and extracurricular implementation, the enhancement of student learning achievement. The data collection tool is observation, questionnaires and documentation. Quantitative research is the type of research performed in this study. The sampling technique in this study was purposive random sampling, namely all 125 students of MTs N Sekecamtan Sekayu. The approach used is the methodology of descriptive analysis and multiple linear regression. Using SPSS version 23 for windows, the data was analyzed descriptively.From the results of the analysis test shows that; The simultaneous influence of the provision of infrastructure and implementation of extracurricular activities on improving learning achievement. There is a substantial rise in the provision of learning achievement facilities. The implementation of extracurricular activities on student achievement is dramatically growing.
\end{abstract}

(C) 2021 The Authors. Published by IICET.

This is an open access article under the CC BY-NC-SA license (https://creativecommons.org/licenses/by-nc-sa/4.0

\section{Corresponding Author:}

Aminah, A.,

Madrasah Tsanawiyah Negeri Sekecamatan Sekayu, Indonesia

Email: aminahbae1980@gmail.com

\section{Introduction}

Each institution of education wants every student to achieve satisfactory accomplishments. The accomplishments of the students are the primary measurement instrument to assess the success of an educator (Siregar et al., 2017). In relation to the educational process, learning facilities and infrastructure have a very significant role (Inriyani et al., 2017). In the educational process, its presence is completely important, such that learning facilities and infrastructure are included in the components that must exist and are met in the implementation of the educational process. The educational process would encounter the educational process without these facilities and infrastructure (Subakti et al., 2021).

It is also necessary to promote the availability of support facilities when implementing and coaching extracurricular activities in schools (Ariani, 2021; Nofianti, 2019). These extracurricular events are also aimed at improving one of the subject areas of interest to a community of students, such as athletics, arts, and different skills and scouting activities (Daryanto, 2013; Firdianti, 2018). In this study, the extracurricular activities include Tahfidz Qur'an and science. This practice is carried out outside of face-to-face hours, in order to expand horizons or abilities, increase and apply discipline, value awareness and motor skills at school or outside of school (Abi Hamid et al., 2020; Elihami \& Syahid, 2018) 
The stronger and optimal the availability of facilities and resources for tahfiz in schools, the greater the extracurricular growth of tahfiz and of science in schools (Widodo, 2020). Students that are involved in extracurricular activities are one of the variables that impact students' progress in engaging in the teaching and learning process and achieving learning achievement (Rahmawati et al., 2019; Ubaidah, 2014).

\section{Method}

There is a particular research design for the research process. This model outlines the procedures or steps to be followed, the time of the analysis, the sources of data and the circumstances under which the data is collected and how the data is collected and processed (Sukmadinata, 2015). Quantitative research is the type of research carried out in this study. In this analysis, the sampling technique was purposeful random sampling (purposive random sampling). Based on Isaac and Michael's formula, the sampling process is determined (Sugiyono, 2019; Yusuf, 2016). The data analysis approach used in this study is multiple linear regression data analysis techniques with the help of the SPSS version 23 software. Multiple regression is done since the influence of the independent variable on the dependent variable is calculated by 3 variables tested.

Multiple linear regression is a forecast study of the importance of the independent variables' effect To show whether or not there is a functional relationship or a causal relationship between two or more independent Kesumawati and Aridanu variables or more to the dependent variable (Kesumawati \& Aridanu, 2018). This research uses multiple techniques of linear regression analysis, so multiple linear regression analysis must satisfy the data assumptions. The implementation stage of the study involves: analisis deskriptif, analisis inferensial (uji prasyarat dan uji asumsi klasik), analisis Regresi Linear Berganda, analisis hipotesis dan analisis koefisien Determinasi (Agus Irianto, 2016)

\section{Results and Discussions}

The provision of facilities and the introduction of extracurricular activities for the achievement of student learning have seen a substantial increase.

As mentioned above, the results of the data analysis show the simultaneous effect of the provision of infrastructure and the execution of extracurricular activities (Pradini et al., 2016) on the improvement of student success in In Sekayu District, Negeri MTs. This suggests that, if all aspects are achieved concurrently, the provision of facilities and the introduction of extracurricular activities would boost student achievement (Bire et al., 2014; Reka et al., 2020). The joint contribution to student achievement from the provision of facilities and extracurricular activities was 40.1 percent. And the remaining $59.9 \%$ is Other variables that are not researched, such as motivation, interest, methods of learning, and so on, are affected. "

\section{In the provision of facilities for student learning achievement, there is a substantial increase.}

The findings of testing the hypothesis that "there is a significant increase in the provision of infrastructure for student achievement in MTs Negeri in Sekayu District" are proven to be accurate. This means that the learning achievement (Djafri, 2008) of State MTs students in Sekayu District is affected by the learning achievement of State MTs students in Sekayu District Impacted by the facilities supplied by the madrasah. If students can use the existing facilities provided at State MTs in Sekayu District, the learning achievement demonstrated and produced by the students will also be high."

The introduction of extracurricular programs on student learning achievement" has seen a substantial increase.

It is proven that the test results stating that "there is a significant increase in the implementation of extracurricular activities on the learning achievement of State MTs students in Sekayu District" are valid. This suggests that extracurricular activities greatly impact the growth in learning achievement. If extracurricular activities are higher, achievement in learning appears to be high. "Infrastructure provision has an average response score of 3.71 which is in the very good category with the education infrastructure and equipment metric being the highest average response score."

\section{Conclusions}

The simultaneous effect of the provision of facilities and the introduction of extracurricular activities on enhancing learning achievement is shown by the results of the study test. There is a substantial rise in the provision of learning achievement facilities. The implementation of extracurricular activities on student achievement is dramatically growing. 


\section{References}

Abi Hamid, M., Ramadhani, R., Masrul, M., Juliana, J., Safitri, M., Munsarif, M., Jamaludin, J., \& Simarmata, J. (2020). Media pembelajaran. Yayasan Kita Menulis.

Agus Irianto. (2016). Statistik: Konsep Dasar, Aplikasi, dan Pengembangannya (Edisi Keem). Prenadamedia Group.

Ariani, R. (2021). Manajemen Kesiswaan dalam Pengembangan Bakat Siswa melalui Program Ekstrakurikuler di SMA Negeri 1 Sambit Ponorogo. IAIN Ponorogo.

Bire, A. L., Geradus, U., \& Bire, J. (2014). Pengaruh gaya belajar visual, auditorial, dan kinestetik terhadap prestasi belajar siswa. Jurnal Kependidikan: Penelitian Inovasi Pembelajaran, 44(2).

Daryanto. (2013). Administrasi dan manajemen sekolah. Jakarta: Rineka Cipta.

Djafri, N. (2008). Pengaruh kegiatan ekstrakurikuler terhadap prestasi belajar siswa pada Pesantren AlKhaerat Kota Gorontalo. Jurnal Inovasi, 5(3).

Elihami, E., \& Syahid, A. (2018). Penerapan Pembelajaran Pendidikan Agama Islam Dalam Membentuk Karakter Pribadi Yang Islami. Edumaspul: Jurnal Pendidikan, 2(1), 79-96.

Firdianti, A. (2018). Implementasi manajemen berbasis sekolah dalam meningkatkan prestasi belajar siswa. Gre Publishing.

Inriyani, Y., Wahjoedi, W., \& Sudarmiatin, S. (2017). Pengaruh kegiatan ekstrakurikuler terhadap prestasi belajar ips melalui motivasi belajar. Jurnal Pendidikan: Teori, Penelitian, Dan Pengembangan, 2(7), 955-962.

Kesumawati, N., \& Aridanu, I. (2018). Statistik Parametrik Penelitian Pendidikan. Palembang: Noel Fikri.

Nofianti, A. (2019). Pengaruh Kegiatan Ekstrakurikuler dan Motivasi Belajar Terhadap Prestasi Belajar Siswa. JDMP (Jurnal Dinamika Manajemen Pendidikan), 2(2), 120-129.

Pradini, I. K., Rochanah, S., \& Muhammad, A. (2016). Manajemen Mutu dalam Upaya Peningkatan Prestasi Sekolah. IMPROVEMENT: Jurnal Ilmiah Untuk Peningkatan Mutu Manajemen Pendidikan, 3(1), 83-94.

Rahmawati, N., Qahfi, M., \& Mariyanto, A. (2019). Pengaruh Keaktifan Siswa dalam Kegiatan Ekstrakurikuler Terhadap Prestasi Belajar Siswa di SMP. Jurnal Paedagogie Media Kependidikan, Keilmuan Dan Keagamaan, 7(1), 1-12.

Reka, W., Burhanuddin, B., \& Sunandar, A. (2020). PEMBINAAN POTENSI KEPEMIMPINAN SISWA MELALUI LAYANAN EKSTRAKURIKULER. JAMP: Jurnal Administrasi Dan Manajemen Pendidikan, 3(3), 199-207.

Siregar, N., Wahjoedi, W., \& Sunaryanto, S. (2017). NILAI-NILAI PENDIDIKAN KARAKTER PADA TARI SAMAN DAN KAITANNYA DALAM PEMBELAJARAN IPS. Prosiding Seminar Nasional Mahasiswa Kerjasama Direktorat Jenderal Guru Dan Tenaga Kependidikan Kemendikbud 2016.

Subakti, H., Watulingas, K. H., Haruna, N. H., Ritonga, M. W., Simarmata, J., Fauzi, A., Ardiana, D. P. Y., Rahmi, S. Y., Chamidah, D., \& Saputro, A. N. C. (2021). Inovasi Pembelajaran. Yayasan Kita Menulis.

Sugiyono. (2019). Metode Penelitian Kuantitatif dan Kualitatif dan R\&D. Bandung: Alfabeta.

Sukmadinata, N. S. (2015). Metode Penelitian Pendidikan. Bandung: Remaja Rosdakarya.

Ubaidah, S. (2014). Manajemen ekstrakurikuler dalam meningkatkan mutu sekolah. Al-Fikrah: Jurnal Kependidikan Islam IAIN Sulthan Thaha Saifuddin, 5, 56738.

Widodo, A. (2020). Proses Internalisasi Nilai-Nilai Karakter Madrasah Inklusi (Studi Deskriptif Di MI NW Tanak Beak Lombok Barat). Jurnal Pendidikan Islam Al-Ilmi, 3(1).

Yusuf, A. M. (2016). Metode penelitian: kuantitatif, kualitatif \& penelitian gabungan. Jakarta: Kencana. 